\title{
USING BACILLUS MEGATERIUM VAR. PHOSPHATICUM AND CALCIUM SUPER PHOSPHATE FOR MANAGEMENT SESAME WILT DISEASE
}

\author{
M.M. Amin ${ }^{(1)}$, S.B.M. Fawaz ${ }^{(1)}$ and Heba M. Abd-El-Motal ${ }^{(2)}$ \\ (1) Plant Pathol. Res. Inst., ARC, Giza, Egypt. \\ (2) Soil, Water and Environment Res. Inst., ARC, Giza, Egypt.
}

Received: Oct. 12, 2016

Accepted: Nov. 24,2016

\begin{abstract}
Bacillus megaterium var. phosphaticum (BMP) have been used to control sesame wilt disease caused by Fusarium oxysporum f.sp. sesami in the presence of different doses of calcium super phosphate (CSP) at two successive seasons (2014 and 2015). CSP was add with soil preparation at the rate of 1, 2, 3 and $4 \mathrm{gm} /$ pot and 50, 100, 150 and 200 $\mathrm{kg} / \mathrm{fed}$ under greenhouse and field conditions respectively.

$B M P$ plus CSP at the highest concentration either in greenhouse $(4 \mathrm{gm} / \mathrm{pot})$ or field conditions $(200 \mathrm{~kg} / \mathrm{fed})$ was the most effective treatment in reducing sesame wilt disease. Also BMP plus CSP at the rate of $200 \mathrm{~kg} / \mathrm{fed}$ promote plants growth, increased minerals uptake, seed yield and oil concentration under field conditions.
\end{abstract}

Key words: Bacillus megaterium var. phosphaticum, calcium super phosphate, Fusarium oxysporum f.sp. sesami and Sesame.

\section{INTRODUCTION}

Sesame (Sesamum indicum L.) is one of the oldest oil seed crops known, and its use probably goes back to 2130 BC (Weiss, 1983). Almost $100 \%$ of the world's sesame area is found in the developing countries (Ashri, 1998). In Egypt, sesame is grown in many governorates i.e., Ismailia, El-Sharkia, El-Fayum and Sohag. It is considered as the first oil seed crop in Ismailia Governorate, where it used in popular Egyptian foods (Serry and Satour, 1981).Wherever sesame is grown it is liable to be attacked by at least eight economically important fungal diseases (Kolte, 1985) and by 65 species of insects at different stages of its growth (Ahuja \& Bkhetia, 1995), causing considerable yield losses. Fusarium oxysporum f.sp. sesami reported for the first time by Armstrong and Armstrong (1950) in North America and consider the most serious destructive pathogen present in all sesame growing areas in the world including Egypt (Xiao et al., 1992, Raghuwanshia et al., 1995, EL-Shazly et al., 1999 and Ammar et al., 2004).
Phosphorus is one of the major essential macronutrients for biological growth and development (Ehrlich et al., 1990). It is involved in several key plant functions, such as energy metabolism, photosynthesis, respiration, nitrogen fixation, enzyme regulation, nutrient movement within plant and DNA composition. Therefore, Phosphorus is important in cell division and development of new tissue (Hameeda et al., 2008). Generally phosphorus found in soil in insoluble form; phosphate-solubilizing bacteria can help to make it available (Rodríguez and Fraga, 1999, Richardson et al., 2009 and Fernández et al., 2012)

Bacillus megaterium var. phosphaticum belong to plant growth-promoting rhizobacteria (PGPR) and known for its ability to solubilize rock Phosphate material (Schilling et al., 1998). PGPR are rootcolonizing bacteria with beneficial effects, which include plant growth promotion, biological disease control and induced systemic resistance (Kloepper and Schroth, 1981, Kloepper, 1993, Ramamoorthy et al., 2001, Zehnder et al., 2001, Akgül and M. Mirik 2008 and Viruel et al., 2014). Induced 
resistance by PGPR has also been studied in recent years using crop plants and different plant pathogens (Zhou et al., 1992 and Ramamoorthy et al., 2002). This group of bacteria includes Phosphate-Solubilizing Bacteria can convert insoluble phosphates into soluble forms through acidification, chelation, exchange reactions and production of organic acids (Rodríguez and Fraga, 1999). They are found in soil but usually they are not enough in population, therefore inoculation of plants by a target microorganism at higher concentration than that normally found in soil is necessary (Vessey, 2003).

This study aimed to control sesame wilt disease caused by Fusarium oxysporum f.sp. sesami, enhance plant growth, increase seed and oil crop by using Bacillus megaterium var. phosphaticum in the presence of different doses of phosphate fertilizer under greenhouse and field conditions.

\section{MATERIALS AND METHODS The pathogen}

Fusarium oxysporum f.sp. sesami (Zap) Cast was isolated from sesame plants showing wilt symptoms at Mallawy, Menia Governorate. The isolate was identified according to Booth (1971 and 1977) and used to inoculate sterilized barley seeds medium for 3 weeks at $200 \mathrm{C}$ according to Van der Meer et al. (1983) to use as inoculum.

\section{The host}

Sesame seeds cv. Giza 32 were procured from Oil Crops Res. Dept., Field Crops Res. Inst., ARC, Giza, Egypt. Seeds of approximately similar size were surface sterilized in $5 \%$ sodium hypochlorite (Clorox) for 2 min then thoroughly washed in sterilized distilled water and left to air dried under aseptic conditions.

\section{Bacillus megaterium phosphaticum (BMP)}

Phosphate dissolving bacteria Baillus megaterium var. phosphaticum (BMP) kindly obtained from the culture collection of the Agr. Microbiol. Dept., NRC, Dokki, Giza, Egypt. The bacterial strain was propagated in $250 \mathrm{ml}$ conical flasks, each contain $125 \mathrm{ml}$ sterilized nutrient broth medium. The flasks were incubated on a rotary shaker $(120 \mathrm{rpm})$ at $27 \pm 10 \mathrm{C}$ for 5 days, the bacterial cells were washed three times by sterilized distilled water and adjusted to $1 \times 109 \mathrm{cfu} / \mathrm{ml}$ according to Callan et al. (1990). Prepared seeds were thoroughly mixed with bacterial suspension for 5 min with 1\% Arabic gum then left to dry for 2 hrs under aseptic conditions before sowing.

\section{Calcium super phosphate (CSP)}

Calcium super phosphate (15.5\%) was added as one part during soil preparation before seed sowing at the rate of 1, 2, 3 and $4 \mathrm{gm} /$ pot and 50, 100, 150 and $200 \mathrm{~kg} / \mathrm{fed}$ under greenhouse and field conditions respectively (the recommended dose rate of $200 \mathrm{~kg} /$ fed.).

\section{Fungicide}

Topsin M-70\% W.P. (Thiophanate) Diethyl 4-4 (O-phenylene) bis 3thiollophanate, manufacture by Nippa Soda, Japan. Prepared seeds were mixed with Topsin $\mathrm{M}-70 \%$ at the rate of $3 \mathrm{gm} / \mathrm{kg}$ seeds for 5 minutes with $1 \%$ Arabic gum then left to dry for 2 hrs under aseptic conditions before sowing.

\section{Greenhouse experiment}

Pot experiments were carried out in the greenhouse of Onion, Garlic and Oil Crops, Plant Path. Res. Inst., ARC during 2014 and 2015 seasons. $30 \mathrm{~cm}$ in diameter plastic pots filled with sterilized sand-clay soil (1:1 $\mathrm{v} / \mathrm{v}$ ) were infested with the prepared F.oxysporum f.sp. sesami at the rate of $2 \%$ $\mathrm{w} / \mathrm{w}, 7$ days before transplanting. Five pots were used as replicates for each treatment and control (infested pots free treatment). Each pot was seeded with 6 seeds in $1^{\text {st }}$ June and irrigated when needed. Also, the 
recommended dose of potassium sulphate $(48 \%)$ and ammonium sulphate $(20.6 \%)$ at rate of remember follow.

\section{Field experiment}

Field experiment were carried out in complete randomized plots at Mallawy Agric. Res. St., Menia Governorate during 2014 and 2015 successive seasons in a heavily infested soil. Four plots as replicates for each treatment and control (free treatment plots) was adopted. Plot was $12 \mathrm{~m} 2\left(4^{\star} 3 \mathrm{~m}\right)$ contained 4 rows (60 $\mathrm{cm}$ apart). Each row contained 35 hill was sown with 5 seeds in $1^{\text {st }}$ June. Plants were thinned to one plant per hill after 20 days from sowing. The recommended cultural practices for sesame production were adopted throughout the growing seasons.

\section{Treatments}

$\begin{array}{ll}\text { 1- } & \text { BMP + } 50 \mathrm{~kg} \mathrm{CSP} \\ \text { 2- } & \text { BMP + 100 kg CSP } \\ \text { 3- } & \text { BMP + 150 kg CSP } \\ \text { 4- } & \text { BMP + 200 kg CSP } \\ 5- & 200 \mathrm{~kg} \mathrm{CSP} \\ \text { 6- } & \text { BMP } \\ \text { 7- } & \text { Topsin M-70\% } \\ \text { 8- } & \text { Control }\end{array}$

\section{Nitrogen, phosphorus and potassium assessment}

Plants shoot content of $\mathrm{N}, \mathrm{P}$ and $\mathrm{K}$ were measured 90 days after sowing for each season under field conditions as described by Jackson (1967).

\section{Wilt disease incidence, morphological characters, seed yield and oil content}

Percentage of wilted plants was recorded 90 days after sowing for each season under greenhouse and open field (Ziedan, 1998). Plant height, no. of branches/plant, no. of capsules/plant, seed yield and oil content (A.O.A.C., 1980) were determined at the end of each season (July month) under field conditions.

\section{Statistical analysis:}

The data were statistically analyzed and significance among means was assessed by least significant difference (LSD) at $5 \%$ probability level using SAS ANOVA program V.9 (Anonymous, 2014).

\section{Results}

The data present in Table (1) show that all treatments under investigation in the two successive seasons (2014 and 2015) significantly decreased the percentage of infection compared to control in greenhouse. Decrease in infection compared to control ranged between $44.88 \%$ to $22.40 \%$ with BMP plus $4 \mathrm{gm}$ CSP/pot and BMP plus $1 \mathrm{gm}$ $\mathrm{CSP} /$ pot treatments respectively. The treatment with BMP plus $4 \mathrm{gm} \mathrm{CSP/pot} \mathrm{gave}$ best reduction in percentage of infection which it gave $38.32 \%$ compared with either control (81.64\%) or Topsin M-70\% (41.66\%) as mean of two seasons. The combined treatments between BMP and CSP were higher effective more than single treatments either BMP or CSP in reducing percentage of infection. Also, the percentage of infected plants that treated by BMP only increased more than plants that treated by the recommended dose of CSP only. The percentage of infection decreased gradually with the increasing of CSP dose as fertilizer in the presence of BMP in combined treatments.

The data present in Table (2) under field conditions show that all treatments under investigation in the two successive seasons (2014 and 2015) significantly decreased the percentage of infection compared to control. The percent of decrease in infection compared to control ranged from $36.92 \%$ to $26.85 \%$ with BMP plus $200 \mathrm{~kg} \mathrm{CSP} / \mathrm{fed}$ and BMP plus $50 \mathrm{~kg} \mathrm{CSP} / \mathrm{fed}$ treatments respectively. The best treatment in reduction the percentage of infection was BMP plus $200 \mathrm{~kg} \mathrm{CSP} / \mathrm{fed}$ which gave $36.25 \%$ infection compared with $57.47 \%$ infection at control, while Topsin $\mathrm{M}-70 \%$ as check control gave $27.05 \%$ infection in two season mean values. The combined treatments 
Amin, et al.,

between BMP and CSP were higher effective more than single treatments with either BMP or CSP in reducing percentage of infection. Bothe of single treatments i.e., full dose of CSP or BMP treatment, gave the same mean value of two seasons $(40.35 \%$ infection). The percentage of infection decreased gradually with the increasing of CSP dose as fertilizer in the presence of $\mathrm{BMP}$ in combined treatments.

Table (1): Effect of Bacillus megaterium var. phosphaticum, calcium super phosphate and Topsin $M-70 \%$ treatments on percentage of infection by Fusarium oxysporum f.sp. sesami on Giza 32 sesame plants under greenhouse conditions during growing seasons 2014 and 2015.

\begin{tabular}{|c|c|c|c|c|}
\hline Treatment & $\mathbf{2 0 1 4}$ & $\mathbf{2 0 1 5}$ & Mean & Decrease (\%) \\
\hline BMP $^{\star}+\mathbf{1}$ gm CSP $^{\star *}$ & 63.35 & 63.35 & 63.35 & 22.40 \\
\hline BMP + 2 gm CSP $^{\text {gMP }}$ +3 gm CSP & 60.02 & 56.67 & 58.35 & 28.53 \\
\hline BMP & 50.01 & 43.32 & 46.66 & 42.84 \\
\hline BMP + 4 gm CSP & 40.00 & 36.64 & 38.32 & 53.06 \\
\hline 4gm CSP & 43.33 & 46.66 & 45.00 & 44.88 \\
\hline BMP & 63.36 & 66.70 & 65.03 & 20.34 \\
\hline Topsin M-70\% & 40.00 & 43.32 & 41.66 & 48.97 \\
\hline Control & 79.97 & 83.30 & 81.64 & - \\
\hline L.S.D. at 5\% & 11.53 & 10.76 & - & - \\
\hline
\end{tabular}

BMP* Bacillus megaterium var. phosphaticumand as seed dressing, CSP** calcium super phosphate/pot

Table (2): Effect of Bacillus megaterium var. phosphaticum,calcium super phosphate and Topsin $\mathrm{M}-\mathbf{7 0} \%$ treatments on percentage of infection by Fusarium oxysporum f.sp. sesami on Giza 32 sesame plants under natural infested soil at Mallawi Agric. Res. Sta., Menia Governorate during growing seasons 2014 and 2015.

\begin{tabular}{|c|c|c|c|c|}
\hline Treatment & $\mathbf{2 0 1 4}$ & $\mathbf{2 0 1 5}$ & Mean & Decrease (\%) \\
\hline BMP $^{\star}+\mathbf{5 0} \mathbf{~ k g C S P}^{\star *}$ & 41.40 & 42.70 & 42.04 & 26.85 \\
\hline BMP + 100 kgCSP $^{\text {BMP + 150 kgCSP }}$ & 39.65 & 41.76 & 40.70 & 29.18 \\
\hline BMP + 200 kgCSP & 38.25 & 40.70 & 39.48 & 31.31 \\
\hline 200 kgCSP & 41.05 & 39.65 & 40.35 & 36.92 \\
\hline BMP & 40.00 & 41.05 & 40.53 & 29.79 \\
\hline Topsin M-70\% & 26.60 & 27.50 & 27.05 & 52.93 \\
\hline Control & 56.06 & 58.88 & 57.47 & - \\
\hline L.S.D. at 5\% & 1.17 & 1.63 & - & - \\
\hline
\end{tabular}

$\mathrm{BMP}^{*}$ Bacillus megaterium var. phosphaticumand as seed dressing, CSP** calcium super phosphate/fed 
Generally, the data present in Tables (1) and (2) clearly show that BMP plus the highest dose of CSP treatment gave the best reduction in the percentage of infection either in greenhouse or field conditions.

According to the mean value of two seasons, the present data in Table (3) show that all treatments under investigation increased seed yield and oil content more than control and Topsin $\mathrm{M}-70 \%$ treatments, except BMP plus $50 \mathrm{~kg} \mathrm{CSP} / \mathrm{fed}$ treatment in seed yield which have no significant different with Topsin M-70\% at two successive season. Seed yield increased by $69.05 \%$ and $18.10 \%$ with BMP plus $200 \mathrm{~kg}$ CSP/fed and BMP plus $50 \mathrm{~kg}$ CSP/fed treatments respectively, while Topsin $\mathrm{M}-70 \%$ gave $20.00 \%$ increase compared to control. From other hand, oil content increased under all treatments more than control and Topsin M$70 \%$. Oil content increase ranged between $12.48 \%$ with $200 \mathrm{~kg} \mathrm{CSP} / \mathrm{fed}$ and $4.56 \%$ with BMP plus $50 \mathrm{~kg} \mathrm{CSP} / \mathrm{fed}$, while Topsin $\mathrm{M}-70 \%$ increased oil content by $4.51 \%$ compared to control. Generally, BMP plus $200 \mathrm{~kg} \mathrm{CSP} / \mathrm{fed}$ treatment gave heights seed yield and oil content/fed which gave 4.44 arddab/fed and $55.79 \%$ oil followed by BMP plus $150 \mathrm{~kg} \mathrm{CSP} / \mathrm{fed}$ which gave 3.66 arddab/fed and $56.04 \%$ oil, while $200 \mathrm{~kg}$ $\mathrm{CSP} / \mathrm{fed}$ as single treatment came in the third position with 3.44 arddab/fed and 57\% oil compared with 2.63 arddab/fed and 133.29 unit oil/fed with control treatment.

The data present in Table (4) show that all treatments under investigation increased plant height, no. of branches/ plant and no. of capsules/ plant significantly more than control except BMP plus $50 \mathrm{~kg} \mathrm{CSP} / \mathrm{fed}$ treatment on plant height which have no significant different with control. All treatments increased the tested parameters more than Topsin $\mathrm{M}-70 \%$ which decrease plant height $(-1.30 \%)$ and gave the lowest percent of increasing in no. of branches/plant (9.74\%) and no. of capsules/ plant $(3.17 \%)$ compared with control. BMP plus $200 \mathrm{~kg} \mathrm{CSP} / \mathrm{fed}$ treatment was the best one in increase plant height and no. of branches/ plant which gave $190.69 \%$ and $85.39 \%$ increase respectively compared with control. While $200 \mathrm{~kg} \mathrm{CSP} / \mathrm{fed}$ treatment increased no. of capsules/ plant more than BMP plus $200 \mathrm{~kg} \mathrm{CSP} / \mathrm{fed}$ where they gave $51.77 \%$ followed by $47.87 \%$ increase respectively compared with control.

According to mean values, the data present in Table (5) show that all treatments increased $\mathrm{N}, \mathrm{P}$ and $\mathrm{K}$ content in plant more than control except BMP plus $100 \mathrm{~kg}$ $\mathrm{CSP} / \mathrm{fed}$ treatment which decreased $\mathrm{N}$ content by $-4.23 \%$ less than control. Also, all treatments increased plants content of $\mathrm{N}, \mathrm{P}$ and $\mathrm{K}$ more than Topsin M-70\% except BMP plus $25 \mathrm{~kg} \mathrm{CSP} / \mathrm{fed}$ and $100 \mathrm{~kg} \mathrm{CSP} / \mathrm{fed}$ treatments. BMP plus $200 \mathrm{~kg} \mathrm{CSP} / \mathrm{fed}$ treatment increased plants content of $\mathrm{N}$ and $\mathrm{K}$ more than any other treatments where it gave $21.14 \%$ and $18.09 \%$ increase more than control respectively. While both of BMP plus $200 \mathrm{~kg} \mathrm{CSP} / \mathrm{fed}$ and $200 \mathrm{~kg} \mathrm{CSP} / \mathrm{fed}$ treatments increased $\mathrm{P}$ content by the same percent (102.38\%) compared to control.

Generally, the mentioned results pointed to BMP plus $200 \mathrm{~kg} \mathrm{CSP} / \mathrm{fed}$ as best treatment under investigation for controlling sesame wilt disease caused by Fusarium oxysporum f.sp. sesami and promote healthy growth and minerals uptake which reverses by increase on seed and oil yield. 
Amin, et al.,

Table (3): Effect of Bacillus megaterium var. phosphaticum, calcium super phosphate and Topsin $\mathrm{M}-70 \%$ treatments on seed yield and oil content on Giza 32 sesame plants under natural infested soil by Fusarium oxysporum f.sp. sesami at Mallawi Agric. Res. Sta., Menia Governorate during growing seasons 2014 and 2015.

\begin{tabular}{|c|c|c|c|c|c|c|c|c|}
\hline \multirow[b]{2}{*}{ Treatment } & \multicolumn{4}{|c|}{ Seed yield (arddab/fed) } & \multicolumn{4}{|c|}{ Oil content $\%$} \\
\hline & 2014 & 2015 & Mean & $\begin{array}{c}\text { Increase } \\
(\%)\end{array}$ & 2014 & 2015 & Mean & $\begin{array}{c}\text { Increase } \\
(\%)\end{array}$ \\
\hline $\mathrm{BMP}^{\star}+50 \mathrm{kgCSP}^{\star *}$ & 3.00 & 3.20 & 3.10 & 18.10 & 52.00 & 54.00 & 52.99 & 4.56 \\
\hline BMP + 100 kgCSP & 3.08 & 3.65 & 3.36 & 28.10 & 53.88 & 54.13 & 54.00 & 6.56 \\
\hline BMP + 150 kgCSP & 3.50 & 3.83 & 3.66 & 39.52 & 56.20 & 55.88 & 56.04 & 10.58 \\
\hline BMP + 200 kgCSP & 4.33 & 4.55 & 4.44 & 69.05 & 56.58 & 55.00 & 55.79 & 10.09 \\
\hline 200 kgCSP & 3.25 & 3.63 & 3.44 & 30.95 & 57.25 & 56.75 & 57.00 & 12.48 \\
\hline BMP & 3.28 & 3.48 & 3.38 & 28.57 & 56.25 & 55.70 & 55.98 & 10.46 \\
\hline Topsin $M-70 \%$ & 3.05 & 3.25 & 3.15 & 20.00 & 53.63 & 52.30 & 52.96 & 4.51 \\
\hline Control & 2.58 & 2.68 & 2.63 & - & 50.50 & 50.85 & 50.68 & - \\
\hline L.S.D. at $5 \%$ & 0.38 & 0.25 & - & - & 1.53 & 1.41 & - & - \\
\hline
\end{tabular}

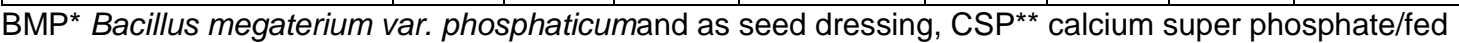

Table (4): Effect of Bacillus megaterium var. phosphaticum,calcium super phosphateand Topsin $M-70 \%$ treatments on Plant height, no. of branches/plant and no. of capsules/plant oil content on Giza 32 sesame plants under natural infested soil by Fusarium oxysporum f.sp. sesami at Mallawi Agric. Res. Sta., Menia Governorate during growing seasons 2014 and 2015.

\begin{tabular}{|c|c|c|c|c|c|c|c|c|c|c|c|c|}
\hline \multirow{2}{*}{ Treatment } & \multicolumn{4}{|c|}{ Plant height (cm) } & \multicolumn{4}{|c|}{ No of branches/plant } & \multicolumn{4}{|c|}{ No of capsules/plant } \\
\hline & 2014 & 2015 & Mean & $\begin{array}{c}\text { Increase } \\
(\%)\end{array}$ & 2014 & 2015 & Mean & $\begin{array}{c}\text { Increase } \\
(\%)\end{array}$ & 2014 & 2015 & Mean & $\begin{array}{c}\text { Increase } \\
(\%)\end{array}$ \\
\hline $\mathrm{BMP}^{\star}+50 \mathrm{kgCSP}^{\star \star}$ & 175.00 & 179.80 & 177.38 & -0.07 & 4.50 & 4.50 & 4.50 & 34.83 & 130.50 & 133.50 & 132.00 & 28.62 \\
\hline BMP + 100 kgCSP & 184.63 & 184.50 & 184.56 & 3.98 & 4.88 & 5.08 & 4.98 & 49.06 & 135.75 & 137.75 & 136.75 & 33.25 \\
\hline BMP + 150 kgCSP & 184.00 & 186.13 & 185.06 & 4.26 & 5.63 & 5.68 & 5.65 & 69.29 & 143.25 & 144.50 & 143.88 & 40.19 \\
\hline BMP + 200 kgCSP & 190.25 & 191.13 & 190.69 & 7.43 & 6.00 & 6.38 & 6.19 & 85.39 & 150.25 & 153.25 & 151.75 & 47.87 \\
\hline $200 \mathrm{kgCSP}$ & 185.00 & 190.00 & 187.50 & 5.63 & 5.50 & 5.53 & 5.51 & 65.17 & 156.00 & 155.50 & 155.75 & 51.77 \\
\hline BMP & 181.50 & 183.88 & 182.69 & 2.92 & 5.13 & 5.45 & 5.29 & 58.43 & 133.50 & 109.75 & 121.63 & 18.51 \\
\hline Topsin M-70\% & 173.88 & 176.50 & 175.19 & -1.30 & 3.63 & 3.70 & 3.66 & 9.74 & 106.00 & 105.75 & 105.88 & 3.17 \\
\hline Control & 175.63 & 179.38 & 177.50 & - & 3.25 & 3.43 & 3.34 & - & 103.50 & 101.75 & 102.63 & - \\
\hline L.S.D. at $5 \%$ & 1.44 & 3.05 & - & - & 0.56 & 0.33 & - & - & 3.85 & 2.90 & - & - \\
\hline
\end{tabular}

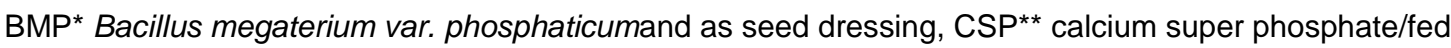


Table (5): Effect of Bacillus megaterium var. phosphaticum, calcium super phosphate and Topsin $\mathrm{M}-70 \%$ treatments on Giza 32 sesame plants shoot content of $\mathbf{N}, \mathbf{P}$ and $\mathrm{K}$ under natural infested soil by Fusarium oxysporum f.sp. sesami at Mallawi Agric. Res. Sta., Menia Governorate during growing seasons 2014 and 2015.

\begin{tabular}{|c|c|c|c|c|c|c|c|c|c|c|c|c|}
\hline \multirow{2}{*}{ Treatment } & \multicolumn{4}{|c|}{$\mathbf{N}(\%)$} & \multicolumn{4}{|c|}{$\mathbf{P}(\%)$} & \multicolumn{4}{|c|}{ K (\%) } \\
\hline & 2014 & 2015 & Mean & $\begin{array}{c}\text { Increase } \\
(\%)\end{array}$ & 2014 & 2015 & Mean & $\begin{array}{c}\text { Increase } \\
(\%)\end{array}$ & 2014 & 2015 & Mean & $\begin{array}{c}\text { Increase } \\
(\%)\end{array}$ \\
\hline $\mathrm{BMP}^{\star}+50 \mathrm{kgCSP}^{\star \star}$ & 0.90 & 0.90 & 0.87 & 1.17 & 0.20 & 0.10 & 0.14 & 32.14 & 1.20 & 1.30 & 1.28 & 8.83 \\
\hline BMP+100 kgCSP & 0.84 & 0.80 & 0.82 & -4.23 & 0.13 & 0.15 & 0.14 & 30.95 & 1.25 & 1.25 & 1.25 & 6.38 \\
\hline $\mathrm{BMP}+150 \mathrm{kgCSP}$ & 0.95 & 1.00 & 0.98 & 13.70 & 0.20 & 0.13 & 0.16 & 54.76 & 1.28 & 1.35 & 1.31 & 11.70 \\
\hline $\mathrm{BMP}+200 \mathrm{kgCSP}$ & 1.03 & 1.05 & 1.04 & 21.14 & 0.20 & 0.23 & 0.21 & 102.38 & 1.38 & 1.40 & 1.39 & 18.09 \\
\hline 200 kgCSP & 1.04 & 1.03 & 1.03 & 20.26 & 0.23 & 0.20 & 0.21 & 102.38 & 1.23 & 1.30 & 1.26 & 7.45 \\
\hline BMP & 0.95 & 1.00 & 0.98 & 13.70 & 0.13 & 0.18 & 0.15 & 42.86 & 1.20 & 1.28 & 1.24 & 5.32 \\
\hline Topsin $\mathbf{M}-\mathbf{7 0} \%$ & 0.85 & 0.95 & 0.90 & 4.96 & 0.09 & 0.15 & 0.12 & 15.48 & 1.18 & 0.88 & 1.03 & -12.77 \\
\hline Control & 0.84 & 0.88 & 0.86 & - & 0.09 & 0.13 & 0.11 & - & 1.15 & 1.20 & 1.18 & - \\
\hline L.S.D. at $5 \%$ & 0.08 & 0.11 & - & - & 0.09 & 0.08 & - & - & 0.08 & 0.30 & - & - \\
\hline
\end{tabular}

BMP $^{*}$ Bacillus megaterium var. phosphaticumand as seed dressing, CSP ${ }^{* *}$ calcium super phosphate/fed

\section{Discussion}

PGPR are root-colonizing bacteria able to exert beneficial effects, which include plant growth promotion, use as biofertilizers, biological disease control and induced systemic resistance (Kloepper, 1993, Ramamoorthy et al., 2001and Zehnder et al., 2001). Phosphorus is one of the major essential macronutrients for biological growth and development (Ehrlich, 1990). The biggest reserves of phosphorus are rocks and other deposits, such as primary apatite and other primary minerals formed during the geological age and organic matter (Paul and Clark, 1988). Several reports have examined the ability of different bacterial species to solubilize insoluble phosphate compounds, such as tricalcium phosphate, di-calcium phosphate, hydroxyl apatite and rock phosphate (Goldstein, 1986). There are considerable populations of phosphate solubilizing bacteria in soil and in plant rhizospheres (Sperberg, 1958 and Alexander, 1977). Considerable concentration of phosphate solubilizing bacteria is commonly found in the rhizosphere in comparison with nonrhizosphere soil include both aerobic and anaerobic strains (Katznelson et al., 1962 and Raghu and MacRae, 1966). Bacillus megaterium var. phosphaticum is known for its ability to solubilize rock phosphate material (Schilling et al., 1998). In this study the combination between Bacillus megaterium var. phosphaticum with different doses of calcium super phosphate approved their capability to control sesame wilt disease and improve minerals uptake, plant growth, seed and oil crop.

Among PGPR, Bacillus spp. and Azotobacter spp., have been reported to be effective against a broad spectrum of plant pathogens, including fungi, bacteria and viruses in many plant species (Morsy et al., 2009, Abd-El-Monaim, 2010 and Mogle and Mane, 2010). Bacillus megaterium has been shown the potential to inhibit or suppress a range of plant diseases, occurring on both the roots and aerial parts of plants (Islam and Nandi, 1985, Liu and Sinclair, 1992, Bertagnolli et al., 1996, Chiou and Wu, 2001, Jock et al., 2002, Jung and Kim, 2005 
and Padgham and Sikora, 2007). Bacillus megaterium significantly reduced severity of pepper crown blight caused by Phytophthora capsici in field experiments (Akgül and Mirik, 2008), reduced growth of Fusarium oxysporum f.sp. Iycopersici significantly and decreased tomato wilt incidence under greenhouse and field conditions (Abd-ElMonaim, et al., 2012). Kong et al. (2010) demonstrated that the marine bacterium Bacillus megaterium could be used as a biocontrol agent against peanut kernels disease caused by $A$. flavus and significantly reduce the biosynthesis of aflatoxins and expression of aflR and aflS gene. Application of PGPR bacteria had stimulation effect on the population of rhizospher microorganisms and increased their numbers significantly (El-Mehrat et al., 2012 and Mahrous et al., 2015). Suppressing pathogens and producing biologically active compounds (Khalid et al., 2004). The effect of PGPR as bio-agents may be due to attacking and binding the pathogenic organisms by sugar linkage and begins to secrete extracellular protease and lipase (Zaghloul et al., 2007) and produce antibiotics products of secondary metabolites such as phenazine-1-carboxilic acid (PCA), 2, 4-Pyrrolnitrin and Oomycin (Ehteshamul-Haque and Ghaffar, 1993 and Knudsen et al., 1995). Several bio-control agents such as Tricoderma spp., Bacillus subtilis and Bacillus megaterium able to control root diseases of sesame in the field (Elewa et al., 2011, Ziedan et al., 2011and 2012).

Application of phosphate solubilizing bacteria to soil or seed helps to improve solubilization of fixed soil phosphorus and to induce plant growth (Broadbent et al., 1977). Bacillus megaterium increased plant growth, quantitative and qualitative parameters of tomato fruits growing under field conditions in two successive seasons and increased fresh and dry weights of survival tomato plants growing in pots compared with control (Abd-El-Monaim, et al., 2012). Plant height, seed weight per plant and 1000-seed weight increased in sesame plants as a result of use Bacillus megaterium (Mahrous et al., 2015). Two strains of Bacillus megaterium increased the pepper yield by 36.2 and 47.7\% under Phytophthora capsici infection (Akgül and Mirik, 2008). Co-inoculation of Bacillus megaterium var. phosphaticum and Bacillus mucilaginosus strains synergistically solubilized rock $P$ and $K$ which were added into the soil and make them much more available for uptake by pepper and cucumber roots (Han and Lee, 2006). Growth enhancement by Bacillus spp. may be associated to its ability to produce hormone, especially IAA (Sheng and Huang 2001), and siderophore (Ito, 1993 and $\mathrm{Hu}$ and Boyer 1996). It is also known that availability of phosphate in soils is important for the uptake of $\mathrm{N}$ from soils and its utilization in plant (Kim et al., 2003). Higher available of phosphate and other nutrients due to the solubilization with inoculation by Bacillus megaterium var. phosphaticum might cause an enhancement of $\mathrm{N}$ uptake, resistance to stress, stabilize soil aggregates and improve soil structure and organic matter content (Al-Taweil et al., 2009). Root colonizing and plant growth promoting bacteria referred to affect plant growth by increasing nutrient cycling, suppressing pathogens and producing biologically active compounds (Khalid et al., 2004). Finally Retain more soil organic $\mathrm{N}$ and other nutrients in the plant-soil system, thus reducing the need for fertilizer $\mathrm{N}$ and $\mathrm{P}$ and enhancing release of the nutrients (Baset et al., 2010).

\section{REFERENCES}

A.O.A.C. (1980). Official Methods of Analysis. Association of Official Agricultural Chemists. 13 teed A.O.A.C., Washington, D.c.

Abd-El-Monaim, M.F. (2010). Integrated management of damping-off, root and/or stem rot diseases of chickpea with sowing date, host resistance and bioagents. Egypt. J. Phytopathol., 38: 4561. 
Abd-El-Monaim, M.F., M.A. Abd-El-Gaid and M.A. El-Morsy (2012). Efficacy of rhizobacteria and humic acid for controlling Fusarium wilt disease and improvement of plant growth, quantitative and qualitative parameters in tomato. J. PI. Pathol., 1: 39-48.

Ahuja, D.B., D.R.C. Bkhetia (1995). Bioecology and management of insect pests of sesame. A review. Journal of Insect Science, 8: 1-19.

Akgül, D.S. and M. Mirik (2008). Biocontrol of Phytophthora capsici on pepper plants by Bacillus megaterium strains. J. Pl. Patholo., 90(1): 29-34.

Alexander, M. (1977). Introduction to Soil Microbiology. New York: Wiley and Sons.

Al-Taweil, H.I., M.B. Osman, A.A. Hamid and W.W.M. Yussof (2009). Development of microbial inoculants and the impact of soil application on rice seedlings growth. Am. J. Agric. Biol. Sci. 4: 79-82.

Ammar, S.E., M.S. El-Shazly, M.A. El-Ashry, M.A. Abd-El-Sattar and M.A.S. ElBramawy (2004). Inheritance of resistance to Fusarium wilt disease in some sesame hybrids. Egypt. J. Appl. Sci. 19: 36-55.

Anonymous, (2014). "Statistical Analysis System". SAS User's Guide: Statistics. SAS Institute Inc. Editors, Cary, NC, 27513, USA.

Armstrong, J.K. and G.M. Armstrong (1950). A Fusarium wilt of sesame in United States. Phytopathol. J., 40: 785.

Ashri, A. (1998). Sesame breeding. In: JANICK J. (ed.): Plant Breeding Reviews. Vol. 16. John Wiley and Sons Inc., New York.

Baset, M.M.A., Z.H. Shamsuddin, Z. Wahab and M. Marziah (2010). Effect of plant growth promoting rhizobacterial (PGPR) inoculation on growth and nitrogen incorporation of tissue cultured Musa plantlets under nitrogen free hydroponics condition. Aust. J. Crop Sci. 4: 85-90.

Bertagnolli, B.L., F.K. DalSoglio and J.B. Sinclair (1996). Extracellular enzyme profiles of the fungal pathogen Rhizoctonia solani isolate 2B-12 and of two antagonists, Bacillus megaterium strain B153-2-2 and Trichoderma harzianum isolate Th008.1. Possible correlations with inhibition of growth and biocontrol. Physiological and Molecular PI. Patholo. 48: 145-160.

Booth, C. (1971). The genus Fusarium. Commonwealth Mycological Institute, Kew, Surrey, England 237pp.

Booth, C. (1977). Fusarium laboratory guide to the identification of the major species. Commonwealth Mycol. Inst. NN. Appl. Biologists, Kew, Surrey, England, p: 158.

Broadbent, P., K.F. Baker, N. Franks and J. Holland (1977). Effect of Bacillus spp. on increased growth of seedlings in steamed and in nontreated soil. Phytopathol. 67: 1027-1034.

Callan, N. W., D. E. Mather and J. B. Miller (1990). Biopriming seed treatment for biological control of Pythium ultimum preemergence damping-off in sh2 sweet corn. PI. Dis., 74: 368-372.

Chiou, A.L. and W.S. Wu, (2001). Isolation, identification and evaluation of bacterial antagonists against elliptica on lily. Phytopathologische Zeitschrift, 149: 319324.

Ehrlich, H.L. (1990). Mikrobiologische und biochemische Ver fahrenstechnik. In: Einsele A, Finn RK, Samhaber W, (ed.) Geomicrobiology, 2nd ed. Weinheim: VCH Verlagsgesellschaft.

Ehteshamul-Haque, S. and A. Ghaffar (1993). Use of rhizobia in the control of root rot diseases of sunflower, okra, soybean and mungbean. J. Phytopathol. 138: 157-163.

Elewa, I.S., A.F. Sahab, M.H. Mostafa and E.H. Ziedan (2011). Direct effect of biocontrol agents on wilt and root-rot diseases of sesame. Archives Phytopathol. PI. Protec., 44(5): 493-504.

El-Mehrat, H.J., A.A. Ragab, S.A. Fawaz and H.H. Abotaleb (2012). Enhancement of Guava fruits quality by using 
biofertilizer. Ann. Agric. Sci. Moushtohor, 50(2): 185-192.

EL-Shazly, M.S., O.A. Abdul Wahid, M.A. ElAshry, S.M. Ammar and M.A.S. ElBramawy (1999). Evaluation of resistance to Fusarium wilt disease in sesame germplasm. Int. J. Pest Manag. 45: 207- 210.

Fernández, L., B. Agaras, P. Zalba, L.G. Wall and C. Valverde (2012). Pseudomonas spp. isolates with high phosphate-mobilizing potential and root colonization properties from agricultural bulk soils under no till management. Biol. Fert. Soils. 48: 763-773.

Goldstein, A.H. (1986). Bacterial solubilization of mineral phosphates: historical perspective and future prospects. Am. J. Altern. Agri., 1: 51-7.

Hameeda, B., G. Harini, O.P. Rupela, S.P. Wani and G. Reddy (2008). Growth promotion of maize by phosphatesolubilizing bacteria isolated from composts and macrofauna. Microbiol. Res. 163: 234-242.

Han, H.S. and K.D.S. Lee (2006). Effect of co-inoculation with phosphate and potassium solubilizing bacteria on mineral uptake and growth of pepper and cucumber. PI. Soil Environ., 52(3): 130136.

Hu, X. and G.L. Boyer (1996). Siderophoremediated aluminum uptake by Bacillus megaterium ATCC 19213. Appl. Environ. Microbiol., 62: 4044-4048.

Islam, K.Z. and B. Nandi (1985). Inhibition of some fungal pathogens of host phylloplane by Bacillus megaterium. Zeitschrift Fur Pflanzenkrankheiten Und Pflanzenschutz-Journal of PI. Dis. Protec., 92: 233-240.

Ito, T. (1993). Enzymatic determination of itoic acid, a Bacillus subtilis siderophore, and 2,3-dihydroxybenzoic acid. Appl. Environ. Microbiol., 59: 2343-2345.

Jackson, M.L. (1967). Soil Chemical Analysis Prentice-Hall of Inia Private limited. New Delhi. pp. 144-197.
Jock, S., B. Volksch, L. Mansvelt and K. Geider (2002). Characterization of Bacillus strains from apple and pear trees in South Africa antagonistic to Erwinia amylovora. Fems Microbiology Letters, 211: 247-252.

Jung, H.K. and S.D. Kim (2005). An antifungal antibiotic purified from Bacillus megaterium KL39, a biocontrol agent of red pepper Phytophthora blight disease. J. Microbiol. Biotechnol., 15: 1001-1010.

Katznelson, H., E.A. Peterson and J.W. Rovatt (1962). Phosphate dissolving microoganisms on seed and in the root zone of plants. Can. J. Bot., 40:11811186.

Khalid, A., M. Arshad and Z.A. Zahir (2004). Screening plant growth-promoting rhizobacteria for improving growth and yield of wheat. J. App. Microbiol., 96: 473-480.

Kim, T., W. Jung, B. Lee, T. Yoneyama, H. Kim and K. Kim (2003). Effects on N uptake and remobilization during regrowth of Italian ryegrass (Lolium mutiflorum). Environ. Exp. Bot., 50: 233242.

Kloepper, J.W. (1993). Plant growthpromoting rhizobacteria as biological agents. In: Metting F.B. Jr., (ed.). Soil Microbial Ecology Applications in Agricultural and Environmental Management, pp. 255-274. Marcel Dekker, New York, NY, USA.

Kloepper, J.W. and M.N. Schroth (1981). Relationship of in vitro antibiosis of plant growth promoting rhizobacteria to plant growth and the displacement of root microflora. Phytopathol., 71: 1020-1024.

Knudsen, I.M.B., J. Hockenhull and D.F. Jensen (1995). Biocontrol of seedling diseases of barley and wheat caused by Fusarium culmorum and Bipolaris sorokiniana: Effects of selected fungal antagonists on growth and yield components. PI. Pathol., 44: 467-477.

Kolte, S.J. (1985). Diseases of Annual Edible Oil Seed Crops. Vol. II: Rapeseed, 
Mustard, Safflower and Sesame Diseases. CRC Press Inc., Boca Raton.

Kong, Q., S. Shan, Q. Liu, X. Wang and F. $\mathrm{Yu}$ (2010). Biocontrol of Aspergillus flavus on peanut kernels by use of a strain of marine Bacillus megaterium. Inter. J. Food Microbiol., 139: 31-35.

Liu, Z.L. and J.B. Sinclair (1992). Population dynamics of Bacillus megaterium strain B153-2-2 in the rhizosphere of soybean. Phytopathol., 82: 1297-1301.

Mahrous, N.M., N.M. Abu-Hagaza, H.H. Abotaleb and Salwa. M.K. Fakhry (2015). Enhancement of growth and yield productivity of sesame plants by application of some biological treatments. American-Eurasian J. Agric. and Environ. Sci., 15(5): 903-912.

Mogle, U.P. and R.Y. Mane (2010). Antagonistic effect of bio-fertilizers against seed born mycoflora of tomato (Lycopersicun esculentum). Res. J. Agri. Sci., 1: 255-258.

Morsy, M. Ebtsam, K.A. Abdel-Kawi and M.N.A. Khalil (2009). Efficiency of Trichoderma viride and Bacillus subtilis as biocontrol agents against Fusarium solani on tomato plants. Egypt. J. Phytopathol., 37: 47-57.

Padgham, J.L. and R.A. Sikora (2007). Biological control potential and modes of action of Bacillus megaterium against Meloidogyne graminicola on rice. Crop Protection 26: 971-977.

Paul, E.A. and F.E. Clark. (1988). Soil microbiology and biochemistry. San Diego, CA: Academic Press, 1988.

Raghu, K. and I.C. MacRae (1966). Occurrence of phosphate-dissolving microorganisms in the rhizosphere of rice plants and in submerged soils. J. Appl. Bacteriol. 29: 582-586.

Raghuwanshia, K.S., N.N. Kune, C.D. Deokar, D.M. Veer and R.W. Bharud (1995). Seed-Borne infection of Fusarium oxysporum f.sp. sesami in different sesame cultivars. Sesame and Safflower Newsletter, 7: 24 -25.
Ramamoorthy, V., T. Raguchander and R. Samiyappan (2002). Enhancing resistance of tomato and hot pepper to pythium diseases by seed treatment with fluorescent Pseudomonads. European J. PI. Pathol. 108: 429-441.

Ramamoorthy, V., R. Viswanathan, T. Raguchander, V. Prakasan and R. Samiyappan (2001). Induction of systemic resistance by plant growth promoting rhizobacteria in crop plants against pests and diseases. Crop Protection 20: 1-11.

Richardson, A.E., P.J. Hocking, R.J. Simpson and T.S. George (2009). Plant mechanisms to optimize access to soil phosphorus. Crop Pasture Sci. 60: 124143.

Rodríguez, H. and R. Fraga (1999). Phosphate solubilizing bacteria and their role in plant growth promotion. Biotechnol. Adv. 17: 319-339.

Schilling, G., A. Gransee, A. Deubel, G. Lezovic and S. Ruppel (1998). Phosphorus availability, root exudates, and microbial activity in the rhizosphere. Z. Pfl. Ernähr. Bodenkde, 161: 465-478.

Serry, M. and M. Satour (1981). Major disease of sesame and sources of resistance in Egypt. FAO PI. Produc. Protec. Paper 29: 71-72.

Sheng, X.F. and W.Y. Huang (2001). Physiological characteristics of strain NBT of silicate bacterium. Acta Pedol. Sci., 38: 569-574.

Sperberg, J.I. (1958). The incidence of apatite-solubilizing organisms in the rhizosphere and soil. Aust. J. Agric. Res., 9:778a.

Van der Meer, Q.P., J.L. Van Bennekom and A.C. Van der Giessen (1983). Screening for resistance to white rot caused by Sclerotium cepivorum Berk. in onions (Allium cepa L.) and leek (Allium porrum L.). Euphytica, 32: 697-701.

Vessey, K. (2003). Plant growth promoting rhizobacteria as biofertilizers. PI. Soil., 255: 571-586. 


\section{Amin, et al.,}

Viruel, E., L.E. Erazzú, L. Martínez Calsina, M.A. Ferrero, M.E. Lucca and F. Siñeriz (2014). Inoculation of maize with phosphate solubilizing bacteria: effect on plant growth and yield. J. Soil Sci. PI. Nutri., 14(4): 819-831.

Weiss, E.A. (1983). Oil seed crops. Longman, London, New York.

Xiao, T.H., X.Y. Feng and X.R. Zhang (1992). Evaluation of introduced sesame germplasm. Crop Genetic Resources 4: 38-39.

Zaghloul, R.A., Hanafy, A., Neweigy N.A. Ehsan and Neamat A. Khalifa (2007). Application of biofertilization and biological control for tomato production. 12th Con. of Microbiology, Cairo, Egypt, 198-212.

Zehnder, G.W., J.F. Murphy, E.J. Sikora and J.W. Kloepper (2001). Application of rhizobacteria for Induced resistance. Euro. J. PI. Pathol., 107: 39-50.

Zhou, T., L. Rankin and T.C. Paulitz (1992). Induced resistance in the biological control of Pythium aphanidermatum by Pseudomonas spp. on European cucumber. Phytopathol., 82: 1080.

Ziedan, E.H.E. (1998). Integrated control of wilt and root-rot diseases of sesame in A.R.E. Ph.D. thesis, Faculty of Agric. Ain Shams Univ., 169 pp.

Ziedan, E.H., I.S. Elewa, M.H. Mostafa and A.F. Sahab (2011). Application of mycorrhizae for controlling root diseases of sesame. PI. Protec. Res. J., 51(4): 355-367.

Ziedan, E.H., M.H. Mostafa and I.S. Elewa (2012). Effect of bacterial inocula on Fusarium oxysporum f.sp. sesami and their pathological potential on sesame. J. Agric. Technol., 8(2): 699-709. 
أستخدام Bacillus megaterium var. phosphaticum وسوير فوسفات الكالسبيوم لمقاومة مرض ذبول السمسم

محسن محمدى أمين(1) ، سيد بدوى مصطفى فوّاز (1) ، هبة محمود عبد المتعال (2)

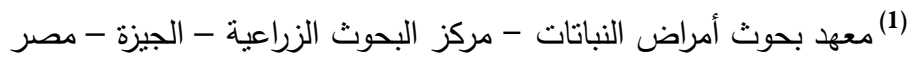

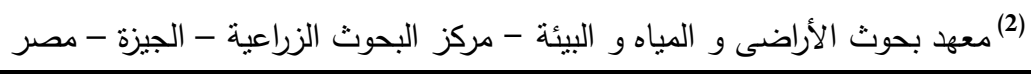

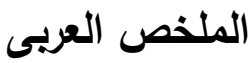
تم أستخدام عزلة بكتيريا Bacillus megaterium var. phosphaticum لمكافحة مرض ذبول السمسم المنسبب عن فطر Fusarium oxysporum f.sp. Sesami فى وجود معدلات مختلفة من سماد سوبر فير

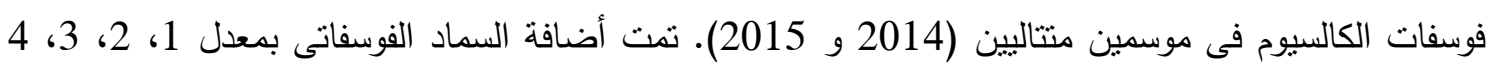

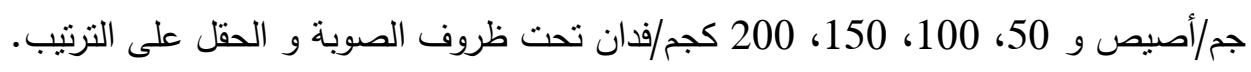

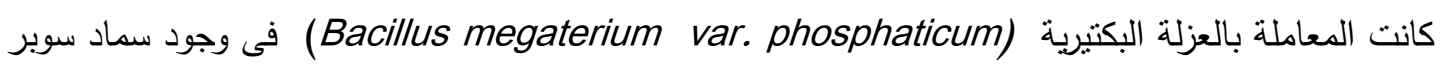

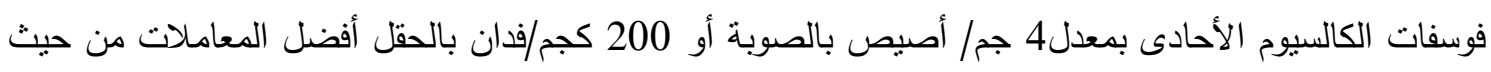

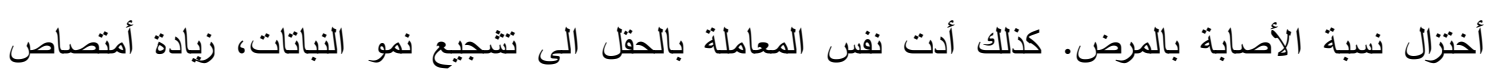
الأملاح، زيادة محصول البذرة و نركيز الزيت. 